\title{
The Relations between QFII Holdings and Company Performance: Evidence from China's A-Share Listed Companies
}

\author{
Xiong Wang, ${ }^{1}$ Shuanghong Zhou, ${ }^{1}$ and Wenqian Fang ${ }^{2}$ \\ ${ }^{1}$ School of Business, Central South University, Changsha, Hunan 410083, China \\ ${ }^{2}$ School of Economics, Fudan University, Shanghai 200433, China \\ Correspondence should be addressed to Shuanghong Zhou; shzhou7230@sohu.com
}

Received 13 March 2014; Revised 4 June 2014; Accepted 6 June 2014; Published 23 June 2014

Academic Editor: Fenghua Wen

Copyright (c) 2014 Xiong Wang et al. This is an open access article distributed under the Creative Commons Attribution License, which permits unrestricted use, distribution, and reproduction in any medium, provided the original work is properly cited.

\begin{abstract}
In order to investigate the relations between qualified foreign institutional investors (QFII) holdings and the performance of the A-share listed companies and effectively distinguish between QFIIs' ability to identify value companies and their ability to enhance company value, this paper empirically examines the relations between QFII holdings and company performance using Chinese annual report data from 2010 to 2012. The results show that QFIIs have strong ability in identifying value companies. However, the effect of QFII holdings on company performance improvement is mainly manifested in the short term, and the long-term effect is insignificant. In the long run, QFIIs may not be considered as "value boosters", implying that it is unlikely for QFIIs to greatly enhance company value and help the invested companies to improve the level of governance and their long-term performance.
\end{abstract}

\section{Introduction}

After nearly two decades of development, China's securities market has been remarkably enhanced either in terms of scale and levels or in terms of functions and efficiency and has become one of Asia's most promising markets. However, due to the QFII investment restriction ratios and QFII investment range limitations, there is still a lot of room for QFIIs to enhance operational efficiency in China's securities market. Early in 2001, both academic experts and practitioners began to suggest that Chinese government introduces QFII scheme as soon as possible in order to compensate for the absence of domestic institutional investors. As China's capital and monetary items are not yet fully open, the QFII scheme is a temporary institutional arrangement that allows licensed foreign institutional investors to invest in China's securities market. The QFIIs may remit a certain amount of foreign currency and convert it into local currency through special channels with the approval of relevant authorities. The capital gains and dividends received can be converted back into foreign currency for repatriation upon approvals. With the continuous development and improvement of this scheme, QFIIs have gradually grown into important investors in China's securities market. According to the latest data released by China's State Administration of Foreign Exchange, as of December 31, 2012, China has awarded a combined $\$ 37.443$ billion of QFII quotas to 169 foreign institutions. The active participation of QFIIs in China's securities market is good for the country's interest rate liberalization and foreign exchange market reformation. It also promotes the opening of China's capital market, the convertibility of RMB capital item, and the backward flow mechanism of offshore RMB as well. Eventually it helps the internalization of RMB. Meanwhile, through holding shares, QFIIs also play an important role in improving governance and performance levels of the invested listed companies.

The analysis of the relations between QFII holdings and the performance of those selected listed companies is really about examining the roles of QFIIs. Are QFIIs "value discoverers" who are good at spotting the best-performing companies or "value boosters" who help improve the governance and performance of the relevant listed companies? Or, do QFIIs act as both? Theoretically speaking, QFIIs as institutional investors with advanced investment philosophy can improve the performance of the invested companies. Compared with the small investors, QFIIs can effectively supervise 
the listed companies to avoid "moral hazard" and reduce the cost of commissions, which helps improve corporate governance and performance. Nevertheless, practically in the not-so-mature Chinese capital market, there are still different voices about whether QFIIs are able to improve corporate performance.

As far as the relevant research at home and abroad is concerned, the relation between QFII holdings and company performance is still a relatively new topic. Most studies have focused on the impact of the general institutional investors on company performance. Based on Pound's study on institutional investors, there are three hypotheses regarding the correlation between QFII holdings and company performance: Efficient Monitoring Hypothesis, Conflict of Interest Hypothesis, and Strategy Alignment Hypothesis [1]. The latter two both hold that QFIIs are unable to improve company performance through enhancing company governance. Whether in the Western countries with matured capital markets or in newly industrialized China in transition, the results of both theoretical and empirical studies are mixed like Pound's three hypotheses. The first category of views believes QFIIs can enhance company governance and thus help to enhance company value $[2,3]$. This viewpoint agrees with Pound's Efficient Monitoring Hypothesis. Most studies on the performance of the listed companies invested by QFIIs show that, compared with the stocks without QFII holdings, companies with QFII participation tend to perform better. Lin and Chen studied the Taiwan stock market and selected 10 stocks with the highest QFII investment ratios and another 10 with the lowest in three different industry sectors as samples and found out that all the 20 stocks showed a significant difference in earnings after the introduction of QFII program. The stocks with higher QFII investment ratios tended to perform much better than the ones with lower ratios [4]. Huang and Shiu conducted another empirical study using Taiwan data and also found out that when factors such as company size and transparency were under control, stocks with higher QFII investment ratios did perform better than those with lower proportions [5]. Khanna and Palepu made use of the data in the 1990s from India and came to the conclusion that QFII holdings and company performance were significantly positively related [6]. Furthermore, Douma et al. found out that, in the Indian stock market, QFIIs who were long-term investors would have positive impact on the performance of the listed companies [7]. Wu et al. collected the information about the top ten shareholders as well as the top ten holders of negotiable stocks released by the A-share listed companies in their semiannual reports and annual reports for years from 2006 to 2009 [8]. They analyzed the role played by QFIIs in A-share market in terms of financial characteristics and company governance. The results of this study showed that companies with QFII holdings did better than those without them in profitability, operational capability, and governance quality. A further regression analysis has proved that QFII holdings could help to enhance company performance to a certain degree. All the above-mentioned studies showed that QFIIs might act as value discoverers. However, the second category of views questions the positive impact of QFII program on company governance [9-12]. They hold that QFII holdings cannot add any value to the selected listed companies. Such a viewpoint applauds Pound's Conflict of Interest Hypothesis and Strategy Alignment Hypothesis. For example, Tan conducted research using data on the listed companies in China and concluded that QFIIs so far had not directly taken part in company governance at all and therefore had only limited positive impact on improving company governance [13].

The limitations of the existing studies mainly lie in three areas. First, most of them narrowly focused on general institutional investors and only a few analyzed directly the relations between QFII holdings and company performance. There is no consistent answer so far to the question about what specific functions QFIIs actually have. Second, the existing studies on the impact of QFII holdings on company performance were mostly based on direct regression analyses with the sum of QFII holdings and company performance in order to test whether QFIIs are able to identify value companies and enhance company value, which has in fact mixed up value discovery and value enhancement. Even if there exists positive relation between them, we cannot conclude that QFIIs are able to discover value or enhance value. Third, chances are that QFII holdings and company performance may be mutually dependent. On the one hand, QFIIs may be involved in company governance and thus help to improve company performance; on the other hand, the best-performing companies may attract more QFIIs and thus help to increase the proportion of shares held by QFIIs. This means that there is reciprocal causality between the two to some extent, which may lead to a serious endogenous problem in the model.

This paper makes an empirical study on the relationship between QFII holdings and company performance using the data for years from 2010 to 2012 released by listed companies in their annual reports. Compared with past studies, the paper bears two unique characteristics. First, studies are performed on the impact of QFII holdings on company performance and on performance enhancement, respectively. This helps to differentiate more effectively between QFII investors' ability to identify value companies and their ability to enhance company value. Second, lag treatment is considered, which to some degree helps to alleviate the so-called endogenous problem that widely existed in prior studies so that the conclusions of the paper are more reliable.

The rest of the paper is organized as follows. In Section 2, we make an introduction of the empirical models. Then we provide data and descriptive statistics in Section 3. In Section 4, we present the empirical evidence and the analyses. Finally, the conclusions will be shown in Section 5.

\section{The Model}

This paper selects company performance and performance improvement as dependent variables. Company performance refers to the operational performance and efficiency of a company which reflects its operating results. While there are many variables used to evaluate company performance, this paper selects three: TOBIN's Q, ROA (return on assets), and ROE (return on equity). They look at company performance, 
TABLE 1: List of study variables.

\begin{tabular}{|c|c|c|c|}
\hline Variable types & $\begin{array}{l}\text { Variable names and } \\
\text { symbols }\end{array}$ & Definition & Calculating method \\
\hline \multirow{6}{*}{ Dependent variables } & ROA & Return on assets & Net profit/average total assets \\
\hline & ROE & Return on equity & Net profit/average net assets \\
\hline & TOBIN_Q & Tobin's Q & Company's market price/company's replacement cost \\
\hline & CROA & Improvement of ROA & ROA of current period minus ROA of last period \\
\hline & CROE & Improvement of ROE & ROE of current period minus ROE of last period \\
\hline & CTOBIN_Q & Improvement of Tobin's Q & $\begin{array}{l}\text { Tobin's Q of current period less than the value of last } \\
\text { period }\end{array}$ \\
\hline Explanatory variables & MaxQFII & Proportion of QFII holdings & $\begin{array}{l}\text { Sum of QFII investment ratios among the top ten } \\
\text { shareholders }\end{array}$ \\
\hline \multirow{7}{*}{ Control variables } & Size & Company size & Period-end total assets \\
\hline & Lev & Debt levels & Liabilities/total Assets \\
\hline & Share & Ownership concentration & Investment ratio of the largest shareholder \\
\hline & Sal & Growth & Main business revenue growth \\
\hline & Tat & Operational capacity & Total assets turnover rate \\
\hline & Industry & Industries, sectors & $\begin{array}{l}\text { Dummy variables, } 11 \text { variables representing } 12 \\
\text { industries }\end{array}$ \\
\hline & Year & Years & Dummy variable, two variables representing three years \\
\hline
\end{tabular}

respectively, from three aspects: capital expansion capability, core achievements, and share price performance.

QFII investment ratio is treated as an independent variable as institutional investors do not have the ability or the incentive to be involved in company governance unless they hold a certain proportion of its shares. According to Giannetti and Laeven, only institutional investors with big scale and strong independence are able to add value to a listed company [14]. Therefore, this paper uses QFII investment ratio among the top ten largest shareholders as an independent variable rather than QFII ratio among all holders.

In addition to QFII investment ratios, some other variables may also influence the performance of a listed company. Based on prior literature in this regard, in order to control the influence of other characteristics of a company, this paper selects such control variables as company size, debt levels, ownership concentration, growth, operational capability, industry sectors, operating years, and so on.

Definitions and symbols for the main variables are shown in Table 1.

Based on the selected samples and regression variables, the intrinsic link between QFII holdings and company performance is examined through establishing regression models. Generally speaking, there are two ways for institutional investors to participate in company governance. First, they buy and sell shares of the listed company but do not involve much in company governance or company decision making. In this situation, institutional investors mainly focus on stock selection and try to identify value companies. They do not intend to help the invested company to enhance value. Second, institutional investors may choose to hold shares for long and thus will actively participate in company governance in order to protect their gains. In this situation, they not only identify value companies but also help to enhance company value. A lot of studies have proved that institutional investors tend to favor the second practice. They try to influence and improve company governance and enhance company value. The paper tries to separate QFIIs' ability to identify value companies and their ability to enhance company value through the following steps.

Step 1. Since the investment decision of QFIIs in period $t$ is made based on company performance in the same and previous periods and the potential company value as well, QFIIs ability to identify value companies can be seen by whether the corresponding listed companies can perform better after QFII involvement. Therefore, this paper makes regression analyses of performance level in period $t$ and QFII investment ratios in lag periods, namely, period $(t-1)$ and period $(t-2)$, in order to examine QFII investors' ability to identify value companies. The established regression models named MODEL I and MODEL II are written as follows:

MODEL I:

$$
\begin{aligned}
Z_{t}= & \alpha_{0}+\alpha_{1} \operatorname{MaxQFII}_{j, t-1}+\alpha_{2} \text { Size }_{j t}+\alpha_{3} \text { Share }_{j t} \\
& +\alpha_{4} \text { Tat }_{j t}+\alpha_{5} \text { Sal }_{j t}+\cdots+\alpha_{6} \operatorname{Lev}_{j} \\
& +\sum_{i=1}^{11} \alpha_{6+i} \text { Industry }_{i}+\sum_{k=1}^{2} \alpha_{17+k} \text { Year }_{k}+\varepsilon ;
\end{aligned}
$$

MODEL II:

$$
\begin{aligned}
Z_{t}= & \alpha_{0}+\alpha_{1} \operatorname{MaxQFII}_{j, t-2}+\alpha_{2} \text { Size }_{j t}+\alpha_{3} \text { Share }_{j t} \\
& +\alpha_{4} \text { Tat }_{j t}+\alpha_{5} \text { Sal }_{j t}+\cdots+\alpha_{6} \text { Lev }_{j} \\
& +\sum_{i=1}^{11} \alpha_{6+i} \text { Industry }_{i}+\sum_{k=1}^{2} \alpha_{17+k} \text { Year }_{k}+\varepsilon
\end{aligned}
$$


TABLE 2: Industry distribution of sample companies.

\begin{tabular}{lcc}
\hline Sectors & Number of companies & The proportion \\
\hline Manufacturing & 135 & $54.66 \%$ \\
Nonmanufacturing & 112 & $45.34 \%$ \\
$\quad$ Agriculture, forestry, animal husbandry, and fishery & 2 & $0.81 \%$ \\
Mining & 6 & $2.43 \%$ \\
Electricity, gas, and water production and supply & 8 & $3.24 \%$ \\
Building industry & 6 & $2.43 \%$ \\
Transportation, storage, and postal & 13 & $5.26 \%$ \\
Information transmission, computer services, and software industry & 18 & $7.29 \%$ \\
Wholesale and retail & 19 & $7.69 \%$ \\
Accommodation and catering & 9 & $3.64 \%$ \\
Financial sector & 15 & $6.07 \%$ \\
Real estate & 11 & $4.45 \%$ \\
Scientific research, technical services, and geological prospecting & 5 & $2.02 \%$ \\
\hline
\end{tabular}

Source: eastern wealth network, GTA database.

where $Z_{t}$ represents performance indicators, ROA, ROE, and TOBIN's $Q$ in period $t$, MaxQFII $_{j, t-1}$ and MaxQFII ${ }_{j, t-2}$ stand for QFII investment ratios in period $(t-1)$ and period $(t-2)$, respectively, $j=1,2,3, \ldots, 247, \alpha_{0}$ indicates a constant, $\alpha_{1}, \alpha_{2}, \ldots, \alpha_{19}$ represent the regression coefficients for corresponding variables, and $\varepsilon$ indicates residuals. MODEL I mainly observes the relation between QFII holdings and performance of invested companies in period $(t-1)$ while MODEL II mainly observes their relation in period $(t-2)$.

Step 2. After having studied QFII investors' ability to identify value companies, the paper selects performance improvement as a dependent variable and makes regression analyses of QFII investment ratios in period $(t-1)$ and period $(t-2)$ in order to examine QFII investors' ability to enhance company value. As for the evaluation of performance improvement, we use such an equation (taking CROE as an example): $\mathrm{CROE}_{t, i}=\left(\mathrm{ROE}_{t, i}-\mathrm{ROE}_{t, I}\right)-\left(\mathrm{ROE}_{t-1, i}-\mathrm{ROE}_{t-1, I}\right)$, where $\mathrm{CROE}_{t, i}$ represents ROE improvement of company $i$ in year $t, \mathrm{ROE}_{t, i}$ indicates ROE for company $i$ in year $t$, and $\mathrm{ROE}_{t, I}$ stands for the mean of the whole industry in year $t$. Such treatment can effectively remove the influence of differences in industry and year on performance improvement and thus makes the evaluation of performance improvement more accurate. The regression models are written as MODEL III and MODEL IV as follows:

\section{MODEL III:}

$$
\begin{aligned}
C Z_{t}= & \alpha_{0}+\alpha_{1} \text { MaxQFII }_{j, t-1}+\alpha_{2} \text { Size }_{j t}+\alpha_{3} \text { Share }_{j t} \\
& +\alpha_{4} \text { Tat }_{j t}+\alpha_{5} \text { Sal }_{j t}+\cdots+\alpha_{6} \text { Lev }_{j} \\
& +\sum_{i=1}^{11} \alpha_{6+i} \text { Industry }_{i}+\sum_{k=1}^{2} \alpha_{17+k} \text { Year }_{k}+\varepsilon ;
\end{aligned}
$$

MODEL IV:

$$
\begin{aligned}
C Z_{t}= & \alpha_{0}+\alpha_{1} \text { MaxQFII }_{j, t-2}+\alpha_{2} \text { Size }_{j t}+\alpha_{3} \text { Share }_{j t} \\
& +\alpha_{4} \text { Tat }_{j t}+\alpha_{5} \text { Sal }_{j t}+\cdots+\alpha_{6} \text { Lev }_{j} \\
& +\sum_{i=1}^{11} \alpha_{6+i} \text { Industry }_{i}+\sum_{k=1}^{2} \alpha_{17+k} \text { Year }_{k}+\varepsilon
\end{aligned}
$$

where $C Z_{t}$ represents company performance indicators, CROA, CROE, and CTOBIN's Q in period $t$, MaxQFII $_{j, t-1}$ and MaxQFII ${ }_{j, t-2}$ represent, respectively, QFII investment ratios in period $(t-1)$ and period $(t-2), j=1,2,3, \ldots, 247$, $\alpha_{0}$ indicates a constant, $\alpha_{1}, \alpha_{2}, \ldots, \alpha_{19}$ are the regression coefficients for corresponding variables, and $\varepsilon$ refers to residuals. MODEL III mainly observes the relation between QFII holdings and performance improvement of the invested companies in lag period $(t-1)$, whereas MODEL IV mainly observes their relation in lag period $(t-2)$.

\section{Data and Descriptive Statistics}

The samples selected for this paper are from the listed companies with QFII holdings annually disclosed by Shanghai Stock Exchange and Shenzhen Stock Exchange in years from 2010 to 2012. Four types of companies are excluded, companies listed in and after 2010, companies without full record of financial data, companies which have also issued $\mathrm{B}$ shares, $\mathrm{H}$ shares, or $\mathrm{S}$ shares, and companies with abnormal data values. Eventually, a total of 247 listed companies are qualified as samples and their industry distribution is shown in Table 2. The industries are classified according to Industry Classification Standard publicized by China's National Bureau of Statistics (http://www.stats.gov.cn/).

As shown in Table 2, of all the selected companies, the number of companies in manufacturing sector amounts to 135 or $54.66 \%$, whereas the number of companies in 
TABle 3: Statistical descriptions.

\begin{tabular}{|c|c|c|c|c|c|c|}
\hline & \multicolumn{2}{|c|}{2010} & \multicolumn{2}{|c|}{2011} & \multicolumn{2}{|c|}{2012} \\
\hline & $\begin{array}{l}\text { QFII invested } \\
\text { companies }\end{array}$ & $\begin{array}{c}\text { A-share listed } \\
\text { companies }\end{array}$ & $\begin{array}{l}\text { QFII invested } \\
\text { companies }\end{array}$ & $\begin{array}{l}\text { A-share listed } \\
\text { companies }\end{array}$ & $\begin{array}{l}\text { QFII invested } \\
\text { companies }\end{array}$ & $\begin{array}{c}\text { A-share listed } \\
\text { companies }\end{array}$ \\
\hline $\mathrm{ROA}$ & 4.86 & 2.26 & 5.08 & 2.16 & 3.30 & 1.87 \\
\hline ROE & 18.10 & 16.28 & 16.01 & 15.25 & 17.13 & 13.32 \\
\hline Tobin_Q & 2.15 & 2.09 & 1.61 & 1.62 & 1.45 & 1.47 \\
\hline Tat & 0.68 & 0.23 & 0.70 & 0.24 & 0.67 & 0.22 \\
\hline Sal & 50.97 & 33.86 & 41.40 & 20.81 & 148.74 & 7.67 \\
\hline Lev & 48.82 & 85.59 & 50.04 & 85.64 & 50.33 & 85.80 \\
\hline Share & 21.86 & 55.79 & 26.42 & 47.63 & 28.51 & 44.82 \\
\hline Size & 11.73 & 3.54 & 13.79 & 4.19 & 15.50 & 4.83 \\
\hline
\end{tabular}

Source: GTA database.

TABle 4: Pearson correlation coefficients.

\begin{tabular}{|c|c|c|c|c|c|c|c|c|c|}
\hline & $\mathrm{ROA}$ & $\mathrm{ROE}$ & Tobin_Q & MaxQFII & Tat & Sal & Lev & Share & Size \\
\hline ROA & 1.0000 & & & & & & & & \\
\hline ROE & 0.3153 & 1.0000 & & & & & & & \\
\hline Tobin_Q & 0.0149 & -0.0039 & 1.0000 & & & & & & \\
\hline MaxQFII & 0.0018 & 0.0034 & 0.0017 & 1.0000 & & & & & \\
\hline Tat & 0.0102 & 0.0030 & -0.0341 & -0.0182 & 1.0000 & & & & \\
\hline Sal & 0.0005 & 0.0001 & -0.0033 & 0.0034 & -0.0042 & 1.0000 & & & \\
\hline Lev & -0.0076 & -0.0027 & 0.0088 & -0.0013 & 0.0056 & 0.0004 & 1.0000 & & \\
\hline Share & -0.0038 & -0.0009 & -0.0131 & -0.0100 & 0.0303 & -0.0013 & 0.0076 & 1.0000 & \\
\hline Size & -0.0096 & 0.0011 & -0.0001 & -0.0021 & 0.0025 & 0.0000 & -0.0056 & 0.0075 & 1.0000 \\
\hline
\end{tabular}

Source: GTA database.

nonmanufacturing sector amounts to 112 or $45.34 \%$. In nonmanufacturing sector, three industries with the highest proportions are wholesale and retail (7.69\%), information transmission, computer services and software (7.29\%), and financial sector $(6.07 \%)$.

Data used in this study mainly come from five sources: annual reports of the listed companies with QFII holdings released by the websites of Shanghai Stock Exchange and Shenzhen Stock Exchange, annual QFII investment ratios disclosed by Eastern Wealth Network, financial data of listed companies with QFII holdings released by GTA database, financial data provided by Wind Information, and China's National Bureau of Statistics.

Table 3 compares the mean values of relevant financial indicators for companies with QFII holdings and those for all A-share listed companies. As shown in the table, in terms of company performance, mean ROA and mean ROE of companies with QFII holdings are both substantially higher than the mean values for all A-share listed companies. This clearly shows that companies invested by QFIIs tend to perform better and QFIIs tend to select value companies. The total assets of companies invested by QFIIs tend to be much more than the mean value of all A-share listed companies, which means QFIIs favor larger companies.

Besides, the proportion of the largest shareholders in companies invested by QFIIs is lower than the mean value of all A-share listed companies. If the proportion of the largest shareholder is used to measure company governance level, we can see that companies invested by QFIIs tend to govern better. Meanwhile, the higher growth rate and operating level of companies invested by QFIIs also prove that they enjoy better governance. Finally, the debt levels of companies invested by QFIIs are smaller than the corresponding mean value of all A-share listed companies, which serves as one of the factors leading to better company performance.

The Pearson correlation coefficients between selected main variables are shown in Table 4.

We can see clearly from Table 4 that the correlation coefficients between the three performance indicators, ROA, ROE, and TOBIN's Q, are relatively larger and the QFII investment ratios have positive relationship with all the three performance indicators although their correlation coefficients are not big (with the correlation coefficient between QFII and ROE the most significant at 0.0034).

\section{Empirical Results}

Table 5 shows the regression results of MODEL I using QFII investment ratio in lag period $(t-1)$ as an independent variable examines QFII investors' ability to identify value companies.

From Table 5 we can see that the independent variable of QFII investment ratio in lag period $(t-1)$ is notably 
TABLE 5: Regression results of QFII investment ratio in period $(t-1)$ and company performance according to MODEL I.

\begin{tabular}{lccc}
\hline Variables & ROA & ROE & Tobin's Q \\
\hline Constant & $0.11531^{* * *}$ & $0.17056^{* *}$ & $1.86739^{* * *}$ \\
& 4.41143 & 2.03436 & 11.04490 \\
MaxQFII(-1) & $0.00849^{* * *}$ & $0.02662^{* *}$ & $0.06213^{* *}$ \\
& 3.42647 & 2.55455 & 2.46714 \\
Size & $0.00000^{* *}$ & $0.00000^{* *}$ & 0.00000 \\
& 2.21042 & 2.24849 & 0.09737 \\
Share & $0.00047^{* * *}$ & $0.00075^{* *}$ & 0.00320 \\
& 2.94002 & 2.29432 & 1.40466 \\
Lev & $-0.21255^{* * *}$ & -0.35712 & $-1.24395^{* * *}$ \\
& -3.45720 & -1.57304 & -4.10290 \\
Sal & 0.00008 & 0.00051 & $0.00425^{* * *}$ \\
& 0.54543 & 0.86615 & 7.63855 \\
Tat & $0.01797^{* * *}$ & $0.03794^{* * *}$ & $0.21312^{*}$ \\
& 2.85683 & 3.01675 & 1.90997 \\
Industry & Yes & Yes & Yes \\
Year & Yes & Yes & Yes \\
\hline Sample & 247 & 247 & 247 \\
$R^{2}$ & 0.34122 & 0.03430 & 0.11295 \\
Adjusted $R^{2}$ & 0.33309 & 0.02233 & 0.10200 \\
$F$-statistic & 41.95437 & 2.86483 & 10.31351 \\
Prob. $F$ & 0.00000 & 0.00943 & 0.00000 \\
\hline Nos & & & $10 \%$ \\
& $s * * *$ & &
\end{tabular}

Notes. ${ }^{* *, * *, *}$ denote statistical significance at the $1 \%, 5 \%$, and $10 \%$ levels, respectively. The upper values of the regression results are regression coefficients while the lower ones are corresponding $T$ statistics.

positively related to each performance indicator, $\mathrm{ROA}, \mathrm{ROE}$, and Tobin's Q. At significance level of $1 \%$, one percentage of increase in QFII investment ratio in lag period $(t-1)$ leads to an ROA increase by 0.00849 ; at significance level of $5 \%$, one percentage of increase in QFII investment ratio in lag period $(t-1)$ leads to an ROE increase by 0.02662 and Tobin's $\mathrm{Q}$ increase by 0.06213 . Of the control variables, company size, ownership concentration, operational capabilities, and growth rate are positively related to performance indicators but negatively related to liability/asset ratio. The $F$ statistics of the regression equations for ROA, ROE, and Tobin's $\mathrm{Q}$ stand at $41.95437,2.86483$, and 10.31351 , respectively. In all three equations, Prob. $F$ representing significance level is smaller than 0.001, which means the regression equations are significant.

According to MODEL II, we take QFII investment ratio in lag period $(t-2)$ as an independent variable to further examine QFII investors' ability to identify long-term company value and the regression results are shown in Table 6.

As shown in Table 6, the independent variable of QFII investment ratio in lag period $(t-2)$ is significantly positively related to each performance indicator, ROA, ROE, and Tobin's Q. At significance level of $1 \%$, one percentage of increase in QFII investment ratio in lag period $(t-2)$ leads to an ROA increase of 0.00993 and ROE increase of 0.01666 ; at significance level of $5 \%$, one percentage of increase in QFII investment ratio in lag period $(t-2)$
TABLE 6: Regression results of QFII investment ratio in period $(t-2)$ and company performance according to MODEL II.

\begin{tabular}{lccc}
\hline Variables & ROA & ROE & Tobin's Q \\
\hline Constant & $0.12674^{* * *}$ & $0.06946^{* * *}$ & $1.66543^{* * *}$ \\
& 3.14283 & 3.16050 & 8.63443 \\
MaxQFII(-2) & $0.00993^{* * *}$ & $0.01666^{* * *}$ & $0.05709^{* *}$ \\
& 2.80691 & 5.14342 & 2.05416 \\
Size & $0.00000^{* *}$ & $0.00000^{* * *}$ & 0.00000 \\
& 2.10072 & 5.66414 & -0.17631 \\
Share & $0.00056^{* *}$ & $0.00077^{* *}$ & 0.00277 \\
& 2.44543 & 2.15816 & 1.26991 \\
Lev & $-0.26210^{* * *}$ & $-0.11981^{* * *}$ & $-0.94633^{* * *}$ \\
& -2.72848 & -3.42330 & -2.60462 \\
Sal & 0.00011 & 0.00031 & $0.00432^{* * *}$ \\
& 0.62405 & 1.03791 & 8.51312 \\
Tat & $0.01506^{* * *}$ & $0.02775^{*}$ & 0.17935 \\
Industry & 2.92032 & 1.87526 & 1.59534 \\
Year & Yes & Yes & Yes \\
\hline Sample & Yes & Yes & Yes \\
$R^{2}$ & 247 & 247 & 247 \\
Adjusted $R^{2}$ & 0.36985 & 0.11315 & 0.08934 \\
$F$-statistic & 0.35403 & 0.09070 & 0.06648 \\
Prob. $F$ & 23.37894 & 5.03950 & 3.90792 \\
\hline Notes. ${ }^{* * * * * * *}$ denote & 0.00000 & 0.00007 & 0.00096 \\
respectively. The upper values of the & regression results & are & regression \\
coefficients while the lower ones are corresponding T statistics. &
\end{tabular}

leads to a Tobin's $\mathrm{Q}$ increase by 0.05709 . The regression results show that QFII ratio in period $(t-2)$ is positively related to company performance and the larger the ratio, the better the performance. Of the control variables, company size, ownership concentration, operational capabilities, and growth rate are positively related to performance indicators but negatively related to liability/asset ratio. The $F$ statistics for the three regression equations stand at 23.37894, 5.03950, and 3.90792, respectively. In all three equations, Prob. $F$ representing significance level is smaller than 0.001 , which means the regression equations are significant.

Overall, results from both MODEL I and MODEL II show that QFIIs are capable of identifying value companies. That is to say, QFIIs as "value discoverers" are able to select betterperforming companies. However, whether QFIIs are "value boosters" and can also help to enhance company performance through active participation in company governance still remains to be seen.

According to MODEL III, we select QFII investment ratio in period $(t-1)$ as an independent variable and the performance improvement indicators of QFII invested companies as dependent variables to examine QFII investors' ability to enhance company value. Regression results are presented in Table 7.

We can see, from Table 7 that except for CTobin's Q, QFII ratio does not have any significant correlation with the other two performance improvement indicators, CROA and 
TABLE 7: Regression results of QFII ratio in period $(t-1)$ and company performance improvement according to MODEL III.

\begin{tabular}{lccc}
\hline Variables & CROA & CROE & CTobin's Q \\
\hline Constant & 0.02217 & 0.25365 & $-0.67125^{* * *}$ \\
& 0.84817 & 1.18952 & -6.56337 \\
MaxQFII(-1) & 0.00309 & -0.01657 & $-0.04722^{* *}$ \\
& 1.36791 & -0.55919 & -2.10425 \\
Size & 0.00000 & 0.00000 & 0.00000 \\
& 1.42781 & -0.25222 & 0.56848 \\
Share & -0.00003 & -0.00490 & 0.00221 \\
& -0.17379 & -1.00645 & 1.32378 \\
Lev & -0.07030 & 0.01079 & $0.65454^{* * *}$ \\
& -1.15191 & 0.03470 & 4.09037 \\
Sal & $0.00025^{* * *}$ & -0.00023 & $0.00300^{* * *}$ \\
& 3.31425 & -0.25646 & 3.38701 \\
Tat & 0.00385 & -0.07649 & -0.04019 \\
Industry & 1.08949 & -0.89436 & -1.01220 \\
Year & Yes & Yes & Yes \\
\hline Sample & Yes & Yes & Yes \\
$R^{2}$ & 247 & 247 & 247 \\
Adjusted $R^{2}$ & 0.03474 & 0.00297 & 0.05507 \\
$F$-statistic & 0.02282 & -0.00942 & 0.04341 \\
Prob. $F$ & 2.91490 & 0.23960 & 4.72068 \\
\hline & 0.00840 & 0.96329 & 0.00011 \\
\hline
\end{tabular}

Notes. ${ }^{* *, * *, *}$ denote statistical significance at the $1 \%, 5 \%$, and $10 \%$ levels, respectively. The upper values of the regression results are regression coefficients while the lower ones are corresponding $T$ statistics.

CROE. At significance level of 5\%, QFII ratio is negatively related to CTobin's Q. Therefore, it can be concluded that QFII holdings do not generate significant performance improvement in short term (one year). In some cases, they may even destroy value.

Next, according to MODEL IV, we use QFII ratio in period $(t-2)$ as an independent variable to examine the performance improvement effect of QFIIs on listed companies in longer term (two years). The regression results are presented in Table 8.

We can see from the regression results shown in Table 8 that QFII ratio does not have any significant correlation with any of the three performance improvement indicators, CROA, CROE, and CTobin's Q. Therefore, QFII holdings do not help much in performance improvement in relatively longer term (two years).

We also find out from Tables 7 and 8 that all listed companies invested by QFII do not show significant performance improvement regardless of short term or long term. It is known that QFIIs may have different expectations behind shareholding. Some may pursue short-term gains through frequent transactions on shares of undervalued listed companies, while others may well look for long-term returns through active participation in company governance which then helps to improve company performance. In order to exclude the influence from short-term gain expectations and further study QFII investors' ability to improve company
TABLE 8: Regression results of QFII ratio in period $(t-2)$ and performance improvement indicators according to MODEL IV.

\begin{tabular}{lccc}
\hline Variables & CROA & CROE & CTobin's Q \\
\hline Constant & 0.03032 & -0.03107 & $-0.42509^{* * *}$ \\
& 0.74699 & -1.39079 & -5.03189 \\
MaxQFII(-2) & 0.00493 & -0.00199 & -0.00827 \\
& 1.44008 & -0.45074 & -0.70662 \\
Size & 0.00000 & 0.00000 & 0.00000 \\
& 1.59043 & 0.20419 & -1.29006 \\
Share & 0.00016 & -0.00021 & 0.00163 \\
& 0.78211 & -0.60593 & 1.09693 \\
Lev & -0.12202 & 0.03209 & $0.49343^{* * *}$ \\
& -1.25216 & 0.46746 & 3.41901 \\
Sal & $0.00027^{* *}$ & $0.00038^{* *}$ & $0.00263^{* * *}$ \\
& 2.06836 & 2.55080 & 3.69150 \\
Tat & 0.00277 & -0.00455 & -0.01835 \\
& 0.56454 & -0.48566 & -0.40938 \\
Industry & Yes & Yes & Yes \\
Year & Yes & Yes & Yes \\
\hline Sample & 247 & 247 & 247 \\
$R^{2}$ & 0.12444 & 0.00548 & 0.06806 \\
Adjusted $R^{2}$ & 0.10246 & -0.01970 & 0.04466 \\
$F$-statistic & 5.66113 & 0.21763 & 2.90893 \\
Prob. $F$ & 0.00002 & 0.97093 & 0.00934 \\
\hline
\end{tabular}

Notes. ${ }^{* *, * *, *}$ denote statistical significance at the $1 \%, 5 \%$, and $10 \%$ levels, respectively. The upper values of the regression results are regression coefficients while the lower ones are corresponding $T$ statistics.

performance, the paper selects 88 listed companies with QFII holdings either in two successive years from 2010 to 2011 or in three successive years from 2010 to 2012. The objective is to examine whether QFIIs are able to enhance company value. First, we use QFII ratio in period $(t-1)$ as an independent variable and the regression results are presented in Table 9.

As shown in Table 9, at significance level of 1\%, QFII ratio in period $(t-1)$ is positively related to the three performance improvement indicators except CTobin's Q. One percentage of increase in QFII investment ratio in lag period $(t-1)$ leads to a CROA increase of 0.00200 and CROE increase of 0.00467 . The regression results show that QFII ratio in period $(t-1)$ is positively related to performance improvement, and the larger the ratio, the more significant the performance improvement. In the first two equations, Prob. $F$ representing significance level is smaller than 0.05 , which means the regression equations are significant. It shows that QFII investors do have positive impact on performance improvement in the short term (one year) and thus act as the so-called role of "value boosters" in the short run.

Then, according to MODEL IV, we select QFII ratio in period $(t-2)$ as an independent variable and the regression results are presented in Table 10.

We can see from Table 10 that the independent variable of QFII investment ratio in period $(t-2)$ is notably related to performance improvement indicators, CROA and CROE. At significance level of $10 \%$, one percentage of increase in QFII 
TABLE 9: Regression results of continuous QFII investment in period $(t-1)$ and company performance improvement according to MODEL III.

\begin{tabular}{lccc}
\hline Variables & CROA & CROE & CTobin's Q \\
\hline Constant & $-0.01755^{* *}$ & -0.01479 & $-0.87958^{* * *}$ \\
& -2.18180 & -1.03486 & -4.34624 \\
MaxQFII(-1) & $0.00200^{* * *}$ & $0.00467^{* * *}$ & -0.00511 \\
& 3.04878 & 2.78349 & -0.35149 \\
Size & $0.00000^{* * *}$ & $0.00000^{* * *}$ & 0.00000 \\
& 4.02036 & 3.24496 & -0.59170 \\
Share & -0.00007 & -0.00027 & $0.00538^{*}$ \\
& -0.73445 & -1.14166 & 1.93553 \\
Lev & -0.01048 & $-0.03748^{*}$ & $0.74865^{* *}$ \\
& -1.07672 & -1.66090 & 2.44204 \\
Sal & $0.00046^{* * *}$ & $0.00177^{* * *}$ & $-0.00524^{* *}$ \\
& 4.39394 & 7.82854 & -2.00151 \\
Tat & $0.02136^{* * *}$ & $0.02249^{*}$ & -0.11674 \\
& 3.51361 & 1.83851 & -1.04473 \\
Industry & Yes & Yes & Yes \\
Year & Yes & Yes & Yes \\
\hline Sample & 88 & 88 & 88 \\
$R^{2}$ & 0.07784 & 0.05540 & 0.09094 \\
Adjusted $R^{2}$ & 0.04510 & 0.02167 & 0.05866 \\
$F$-statistic & 2.37751 & 2.64230 & 2.93642 \\
Prob. $F$ & 0.03130 & 0.01839 & 0.01042 \\
\hline & & &
\end{tabular}

Notes. ${ }^{* * *, * *, *}$ denote statistical significance at the $1 \%, 5 \%$, and $10 \%$ levels, respectively. The upper values of the regression results are regression coefficients while the lower ones are corresponding $T$ statistics.

investment ratio in lag period $(t-2)$ leads to a CROA increase of 0.00179 and at significance level of $5 \%$ one percentage of increase in QFII investment ratio in lag period $(t-2)$ leads to a CROE increase of 0.00630 . In the first two equations, Prob. $F$ representing significance level is less than 0.10 , which means the regression equations are significant. It shows that QFII holdings also help improve company performance in the relatively longer term (two years).

Overall, QFII holdings can help to improve company performance in the first two years. Therefore, we can state that QFIIs do play the role of "value boosters." Nevertheless, in the periods after $(t-2)$ the significance level of the independent variable declines sharply, which means that QFII holdings show strong effect of improving company performance in the short term but not in the long term.

\section{Conclusions}

This paper quantitatively analyzes the relations between QFII holdings and company performance and attempts to make an effective distinction between QFIIs' ability to identify value companies and their ability to enhance company value. We come to the following main conclusions.

First, after performing the regression analyses of QFII investment ratio in lag periods and each of the three performance indicators one by one, ROA, ROE, and Tobin's Q, we can observe that QFII ratios in periods $(t-1)$ and $(t-2)$
TABLE 10: Regression results of continuous QFII investment in period $(t-2)$ and performance improvement according to MODEL IV.

\begin{tabular}{|c|c|c|c|}
\hline Variables & CROA & CROE & CTobin's Q \\
\hline \multirow{2}{*}{ Constant } & $-0.02653^{* *}$ & -0.01873 & $-0.68215^{* * *}$ \\
\hline & -2.15342 & -0.74761 & -2.95152 \\
\hline \multirow{2}{*}{ MaxQFII(-2) } & $0.00179^{*}$ & $0.00630^{* *}$ & -0.01386 \\
\hline & 1.73844 & 2.18170 & -1.03571 \\
\hline \multirow{2}{*}{ Size } & $0.00000^{* * *}$ & $0.00000^{* * *}$ & 0.00000 \\
\hline & 2.81223 & 3.13358 & -1.35747 \\
\hline \multirow{2}{*}{ Share } & -0.00004 & 0.00002 & 0.00112 \\
\hline & -0.31899 & 0.05548 & 0.39436 \\
\hline \multirow{2}{*}{ Lev } & -0.00121 & $-0.08530^{*}$ & $0.87797^{* *}$ \\
\hline & -0.06856 & -1.88554 & 2.61655 \\
\hline \multirow{2}{*}{ Sal } & $0.00054^{* * *}$ & $0.00234^{* * *}$ & $-0.00789^{* * *}$ \\
\hline & 3.62545 & 6.09090 & -3.85868 \\
\hline \multirow{2}{*}{ Tat } & $0.01526^{* *}$ & 0.01489 & -0.05486 \\
\hline & 2.30065 & 0.82115 & -0.39137 \\
\hline Industry & Yes & Yes & Yes \\
\hline Year & Yes & Yes & Yes \\
\hline Sample & 88 & 88 & 88 \\
\hline$R^{2}$ & 0.05947 & 0.09093 & 0.12806 \\
\hline Adjusted $R^{2}$ & 0.01020 & 0.02359 & 0.06348 \\
\hline$F$-statistic & 1.98277 & 2.81754 & 0.85362 \\
\hline Prob. $F$ & 0.07763 & 0.01223 & 0.53266 \\
\hline
\end{tabular}

Notes. ${ }^{* * *, * *, *}$ denote statistical significance at the $1 \%, 5 \%$, and $10 \%$ levels, respectively. The upper values of the regression results are regression coefficients while the lower ones are corresponding $T$ statistics.

are positively related to all the performance indicators. This implies that QFII investors have strong capability to identify value companies and tend to perform well in investing those companies whose shares have been held following due diligence given to the companies' performance level and potential value. Therefore, we can state that QFIIs have done well identifying value companies.

Second, after performing the regression analyses of QFII investment ratio in lag periods and each of the three performance improvement indicators (CTobin's Q, CROA, and CROE), we find that both QFII ratios in periods $(t-1)$ and $(t-2)$ do not have any significant correlation with any of the three performance improvement indicators, which means in full sample QFIIs play less significant roles in performance improvement of the selected companies.

Third, it is known that QFIIs may have different expectations behind shareholding. Some may pursue short-term gains through frequent transactions on shares of undervalued listed companies, while others may look for long-term returns through active participation in company governance which then helps to improve company governance and performance. In order to discard the influence of the short-term gain expectation and further study QFII investors' ability to improve company performance, the paper selects 88 listed companies with QFII holdings either in two successive years from 2010 to 2011 or in three successive years from 2010 to 2012. The objective is to examine whether QFIIs are able 
to boost company value. The results show that both QFII investment ratios in periods $(t-1)$ and $(t-2)$ have remarkably positive impact on company performance. Nevertheless, in periods after $(t-2)$ the significance level of the independent variable declines sharply, which means that QFII holdings show strong effect of improving company performance in the short term but not in the long term.

From the above conclusions, we can see that QFIIs, as qualified foreign institutional investors with advanced investment philosophy and mature investment experience, have shown strong ability to identify value companies. However, QFIIs have shown much less influence on midterm and long-term performance of the listed companies in terms of enhancing company value. The lack of influence of QFIIs on company performance in China can be explained in three aspects.

Firstly, because QFIIs haven not been in China's capital market for very long, they are still at the exploration stage getting to know the country's macroenvironment and how the listed companies are operating here. QFIIs so far do not get much involved in company governance and have limited influence on company value enhancement. Secondly, China's securities market is still in early development without complete and sound governing laws and regulations. Issues brought by allocation of shares are not fully resolved and there are many more speculators on the sidelines than real investors in China's stock market. All these factors inevitably make QFIIs unable to fully play their roles. Lastly, the administrative authorities in China still implement rigid regulations on QFII program, which leads to low QFII investment ratios and high cost in participating in company administration and governance. Therefore, QFII investors generally do not have great interest for participation in company governance.

\section{Conflict of Interests}

The authors declare that there is no conflict of interests regarding the publication of this paper.

\section{Acknowledgment}

This research was supported by the Natural Science Foundation of China under Grant no. 71203241.

\section{References}

[1] J. Pound, "Proxy contests and the efficiency of shareholder oversight," Journal of Financial Economics, vol. 20, pp. 237-265, 1988.

[2] S. Gillan and L. Starks, "Corporate governance, corporate ownership, and the role of institutional investors: a global perspective," Journal of Applied Finance, vol. 13, pp. 4-22, 2003.

[3] M. M. Cornett, A. J. Marcus, A. Saunders, and H. Tehranian, "The impact of institutional ownership on corporate operating performance," Journal of Banking \& Finance, vol. 31, no. 6, pp. 1771-1794, 2007.

[4] A. Lin and C. Chen, "The impact of qualified foreign institutional investors on Taiwan's stock market," Journal of Chinese Management Review, vol. 9, no. 2, pp. 1-27, 2006.
[5] R. D. Huang and C.-Y. Shiu, "Local effects of foreign ownership in an emerging financial market: evidence from qualified foreign institutional investors in Taiwan," Financial Management, vol. 38, no. 3, pp. 567-602, 2009.

[6] T. Khanna and K. Palepu, "Emerging market business groups, foreign investors, and corporate governance," NBER Working Paper 6955, 1999.

[7] S. Douma, R. George, and R. Kabir, "Foreign and domestic ownership, business groups, and firm performance: evidence from a large emerging market," Strategic Management Journal, vol. 27, no. 7, pp. 637-657, 2006.

[8] W. Wu, D. Wan, and D. Cai, "Are qualified foreign institutional investors real investors or speculators? Evidence from China," SSRN Working Paper Series, 2011.

[9] A. Bhide, "The hidden costs of stock market liquidity," Journal of Financial Economics, vol. 34, no. 1, pp. 31-51, 1993.

[10] M. P. Smith, "Shareholder activism by institutional investors: evidence from CalPERS," Journal of Finance, vol. 51, no. 1, pp. 227-252, 1996.

[11] H. Short and K. Keasey, "Institutional voting in the UK: is mandatory voting the answer?" Corporate Governance, vol. 5, no. 1, pp. 37-44, 1997.

[12] D. D. Guercio and J. Hawkins, "The motivation and impact of pension fund activism," Journal of Financial Economics, vol. 52, no. 3, pp. 293-340, 1999.

[13] M. N. T. Tan, "Has the QFII scheme strengthened corporate governance in China?" China, vol. 7, no. 2, pp. 353-369, 2009.

[14] M. Giannetti and L. Laeven, "Pension reform, ownership structure, and corporate governance: evidence from a natural experiment," Review of Financial Studies, vol. 22, no. 10, pp. 4091-4127, 2009. 


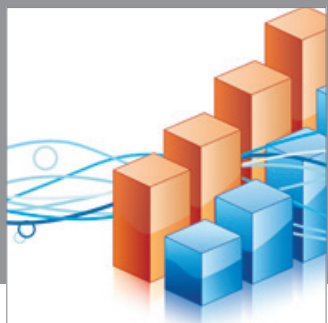

Advances in

Operations Research

mansans

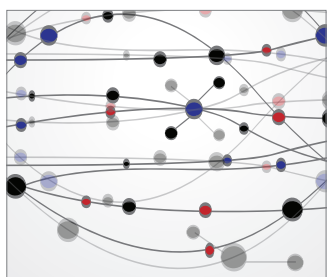

The Scientific World Journal
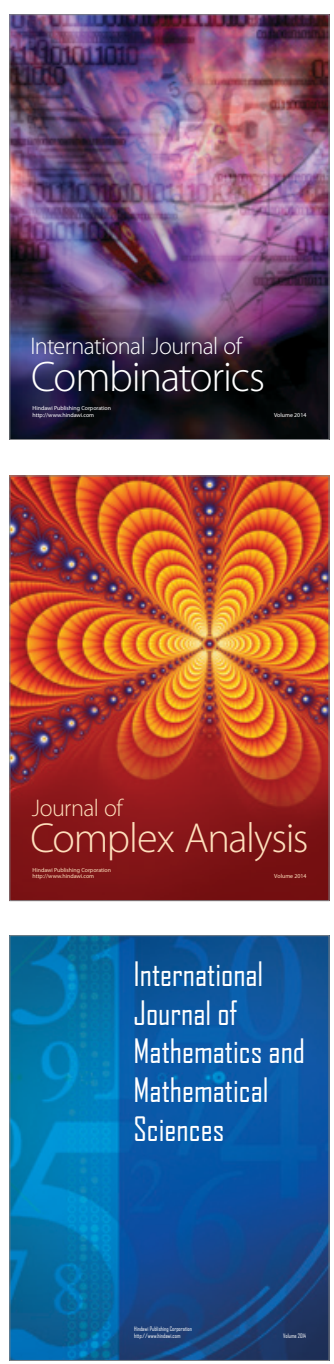
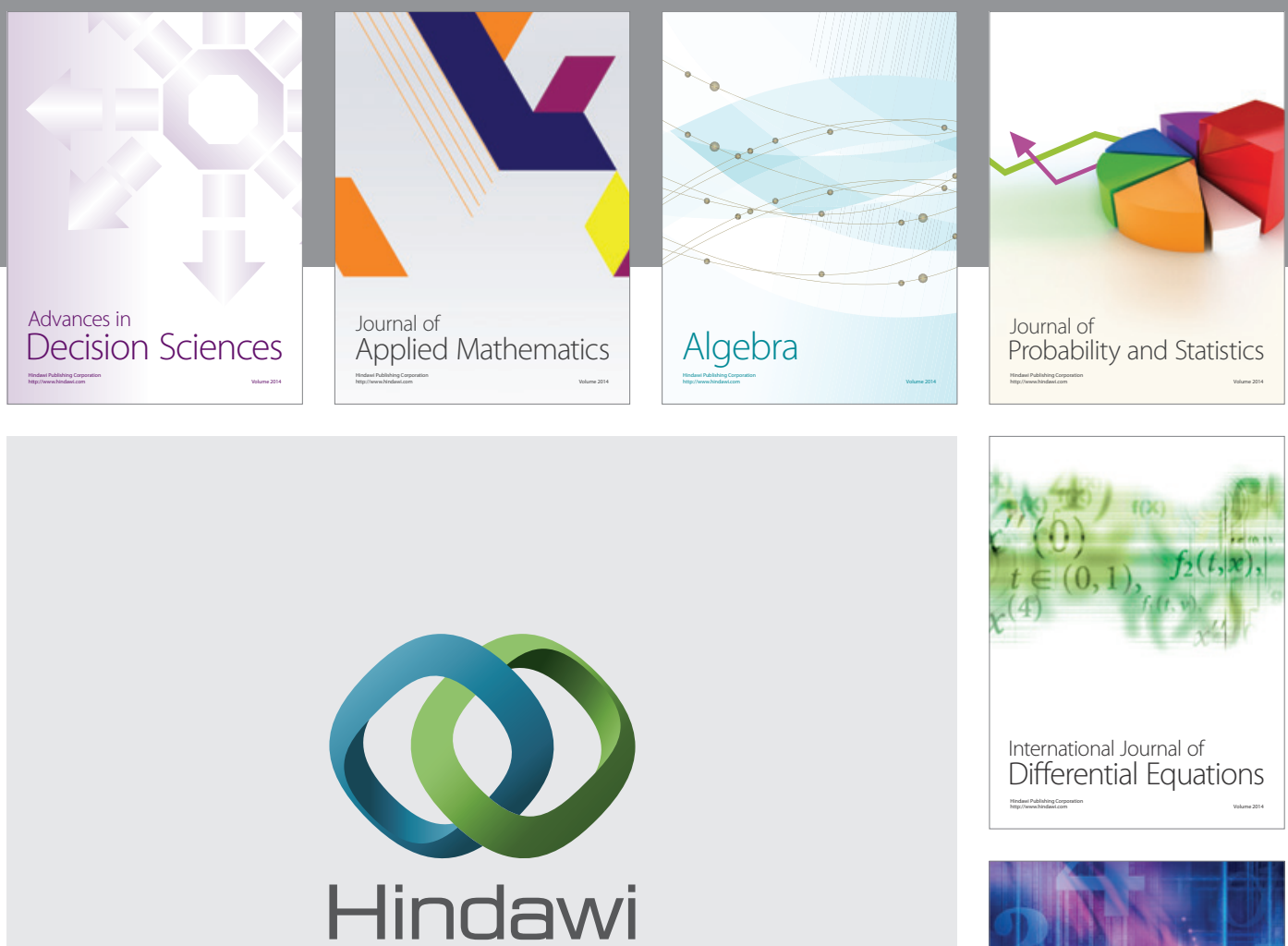

Submit your manuscripts at http://www.hindawi.com
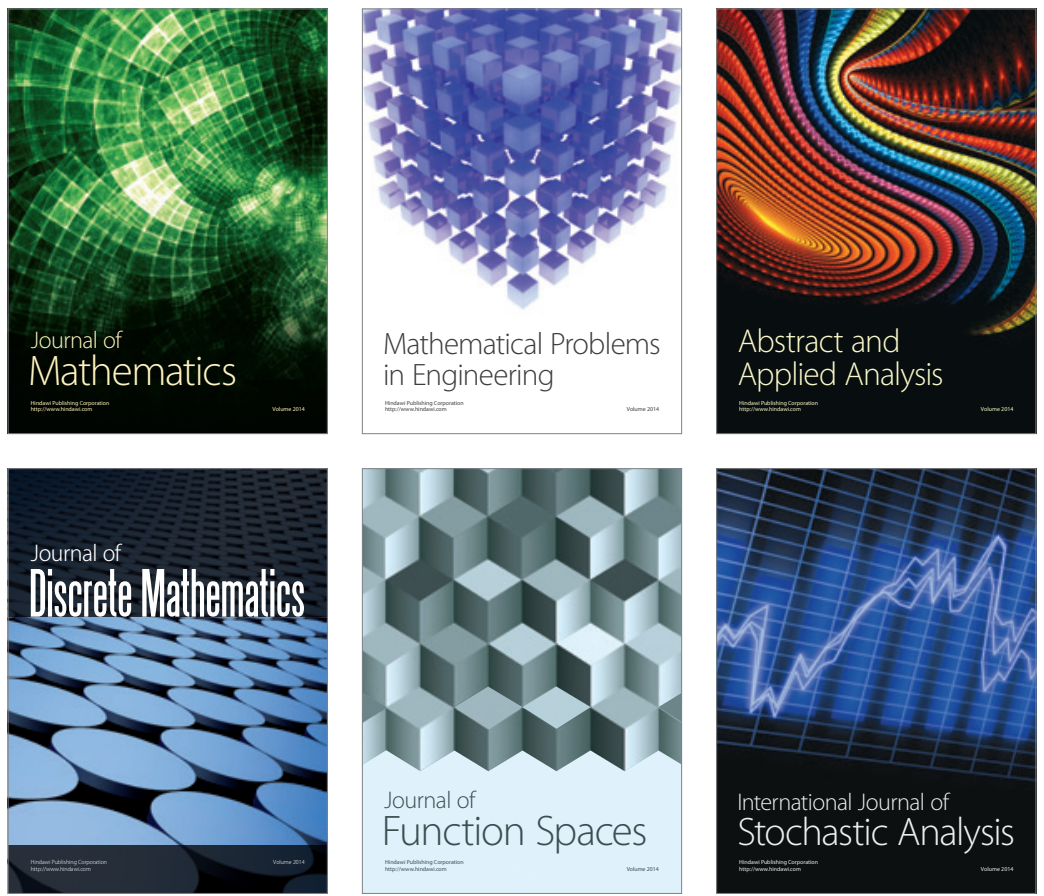

Journal of

Function Spaces

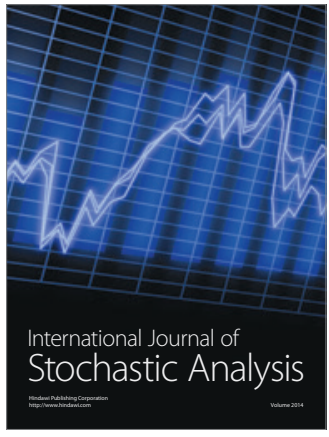

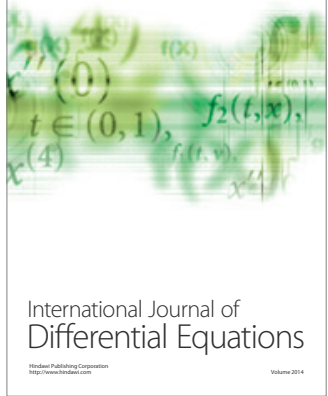
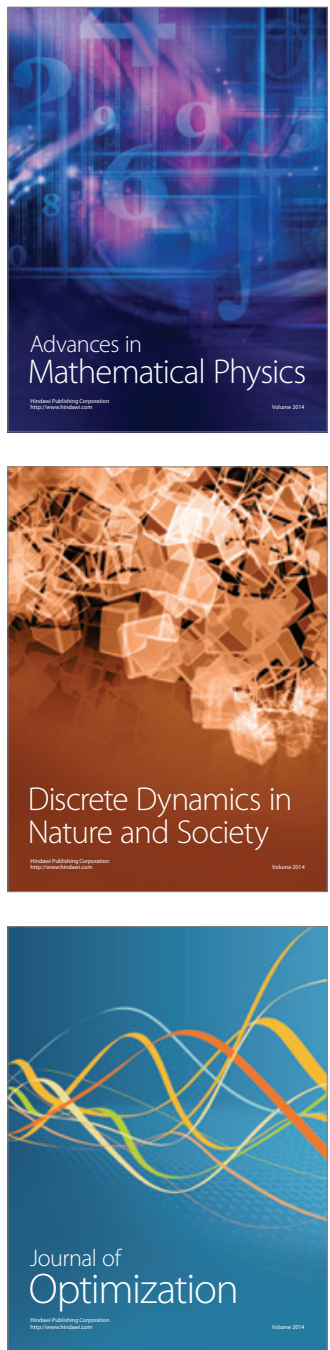